\title{
RENEWED MANAGEMENT SYSTEM AND PROVISIONS FOR SOUTH AFRICA'S SUB-ANTARCTIC ISLANDS
}

\author{
by Sarah J. Davies, Steven L. Chown and Leonie S. Joubert
}

(with three tables)

\begin{abstract}
Davies, S.J., Chown, S.L. \& Joubert, L.S. 2007(23:xi): Renewed management system and provisions for South Africa's sub-Antarctic islands. Papers and Proceedings of the Royal Society of Tasmania 141(1):115-120. https://doi.org/10.26749/rstpp.141.1.115 ISSN 0080-4703. DST. NRF Centre of Excellence for Invasion Biology, Department of Botany and Zoology, Stellenbosch University, Private Bag X1, Matieland 7602, South Africa. (SJD*, SLC, LSJ). *Author for correspondence.
\end{abstract}

\begin{abstract}
A novel environmental management plan (EMP) produced for the Prince Edward Islands provides a systematic and comprehensive set of provisions for the management of the islands' biodiversity and historical estate. The plan addresses four major management goals: administration, conservation management, historical conservation and waste management. The EMP serves both an information-provision and a management-support function within a framework of continual improvement.
\end{abstract}

Key Words: biological invasions, quarantine, waste management, environmental management plan, Prince Edward Island, Marion Island.

\section{INTRODUCTION}

The Prince Edward Islands are situated in the Indian Ocean sector of the Southern Ocean approximately $1770 \mathrm{~km}$ southeast of the South African mainland. The group consists of two islands separated by $19 \mathrm{~km}$ : the larger Marion Island $\left(46^{\circ} 54^{\prime} \mathrm{S}, 37^{\circ} 45^{\prime} \mathrm{E}, 290 \mathrm{~km}^{2}\right)$ and the smaller Prince Edward Island $\left(46^{\circ} 38^{\prime} \mathrm{S}, 37^{\circ} 57^{\prime} \mathrm{E}, 45 \mathrm{~km}^{2}\right)$. Marion Island has a wellestablished research base that has been staffed by a team of technicians and scientists since the annexation of the island by South Africa in 1948. Generally, a single re-supply voyage occurs annually, but in recent years, with the construction of a new research base, visits to supply construction materials and personnel have become more frequent (up to four voyages annually). Prince Edward Island is visited infrequently, having the highest protection status afforded to any land in the territory of South Africa. It also has no infrastructure. The relatively untransformed state and comparatively simple ecosystems of the islands have made them ideal sites for an active and productive bio-physical research programme (e.g., Hänel \& Chown 1999).

The Prince Edward Islands enjoy greater protection than any other land area in South Africa by virtue of their unusual and sensitive biodiversity, which is unique to the few land masses in the Southern Ocean, and in some cases specific to one or both of the islands in the group (Chown et al. 2001). Although the islands are designated a Special Nature Reserve, conservation threats are substantial. Alien species have already been implicated in local species extinctions and have resulted in altered ecosystem functioning (Chown $\&$ Smith 1993, Gremmen et al. 1998, Bergstrom \& Chown 1999, Bester et al. 2002), with further impacts expected as environments continue to change and as new species establish (e.g., Lee et al. 2007).

The effects of climate change and illegal, unregulated and unreported (IUU) fishing are already evident at the islands (Chown \& Smith 1993, Nel \& Nel 1999, Lombard et al. 2007). Further introductions of alien species in the form of pathogens have the potential to cause disease outbreaks which could severely affect species and ecosystems of conservation concern (Daszak et al. 2000).
The first management plan for the Prince Edward Islands was published in 1996, in response to the 1995 proclamation of the islands as a Special Nature Reserve in South African law (Department of Environmental Affairs and Tourism [DEAT] 1996). Although regular review and modification of the management plan was envisaged at the time, the first update was commissioned in 2005 and the drafting of the updated Prince Edward Islands Environmental Management Plan (EMP) was completed early in 2006. During the intervening nine years, the national and international political and legal contexts changed fundamentally, and South Africa now has an advanced set of environmental laws based on an environmental umbrella act (National Environmental Management Act, No. 107 of 1998; Office of the President 1998) that provides for cooperative governance and establishes principles for decision-making. In short, environmental management in South Africa now places people and their needs at the forefront of its concern, and aims to drive development that is socially, environmentally and economically sustainable. Through the National Environmental Management Act, government has established the legislative framework for several sectoral daughter acts such as the National Environmental Management: Protected Areas Act (No. 57 of 2003; The Presidency 2004a) and the National Environmental Management: Biodiversity Act (No. 10 of 2004; The Presidency 2004b), and a number of new institutional structures (e.g., an intra-governmental environmental coordinating committee). In concert with these changes in the regulatory environment, advances in scientific knowledge and environmental practice during the intervening period have altered the range of tools and the quality of information that is available to environmental managers.

\section{APPROACH AND METHODS}

The new Environmental Management Plan (EMP) was developed by the Department of Science and TechnologyNational Research Foundation (DST-NRF) Centre of Excellence for Invasion Biology under contract to DEAT. The 
drafting process took place over a 10 -month period during 2005 and included a review of the previous management plan, intensive examination of legislation and policyand other island management plans, and consultation with academic, publicand private-sector participants in sub-Antarctic operations. Three attributes set this plan apart from the previous Prince Edward Islands Management Plan and from many other management plans.

First, the updated EMP is based on the International Standards Organisation (ISO) principles of quality management, emphasising a systems approach to management, a factual approach to decision-making, and the need for continual improvement. Although the EMP was produced as a specific requirement of national legislation, the ISO 14000series approach brings the plan in line with international standards normally used in voluntary adherence systems.

Second, an integrated life-cycle approach has been used to take into account all phases of project development, from planning and policy-making to implementation and review.
Third, the management provisions of the plan are comprehensive and clearly articulate the actions, targets and roles, and monitoring and remedial actions that will guide management responses to routine and extraordinary situations (table 1). The EMP also serves to provide information for all visitors to the islands since it contains a comprehensive background to the physical, biological and social environment of the islands.

\section{OBJECTIVES OF THE PLAN}

The objectives of the EMP are to conserve and, where necessary, restore biophysical systems on the islands; to meet South Africa's international commitments to Southern Ocean conservation (through at least 20 relevant agreements and protocols, principally the Convention on Biological Diversity, Convention on the Conservation of Antarctic Marine Living Resources, Convention for the Conservation of Antarctic Seals, Agreement on the Conservation of

TABLE 1

A single management objective and its provisions, Prince Edward Islands ${ }^{1}$

\begin{tabular}{|c|c|c|c|c|c|}
\hline Objective & Actions & Target & Monitoring actions & Responsibilities & Remedial actions \\
\hline \multirow[t]{5}{*}{$\begin{array}{l}\text { Minimisa- } \\
\text { tion and safe } \\
\text { handling and } \\
\text { storage of waste } \\
\text { generated at the } \\
\text { field huts }\end{array}$} & $\begin{array}{l}\text { No uncooked } \\
\text { meat, fish, chicken } \\
\text { or egg products } \\
\text { may be supplied } \\
\text { to or transferred } \\
\text { to or stored at the } \\
\text { field huts }\end{array}$ & $\begin{array}{l}\text { Minimise generation } \\
\text { of bio-hazardous } \\
\text { (high risk) waste }\end{array}$ & $\begin{array}{l}\text { Inspections of food } \\
\text { during hut re-sup- } \\
\text { ply; self-regulation } \\
\text { by all over-wintering } \\
\text { and take-over per- } \\
\text { sonnel }\end{array}$ & $\begin{array}{l}\text { Action: all visitors, } \\
\text { DEAT DAI } \\
\text { Monitoring: SCO } \\
\text { and TCO }\end{array}$ & $\begin{array}{l}\text { Any bio-hazardous waste } \\
\text { found at the huts must be } \\
\text { containerised and returned } \\
\text { to the base for freezing; } \\
\text { origin of waste must be } \\
\text { ascertained and followed up } \\
\text { with suitable penalties }\end{array}$ \\
\hline & $\begin{array}{l}\text { Carry out all } \\
\text { bones, paper, } \\
\text { cardboard, batter- } \\
\text { ies etc. and enter } \\
\text { into base waste } \\
\text { stream }\end{array}$ & $\begin{array}{l}\text { Minimisation of } \\
\text { waste accumulation } \\
\text { at the field huts }\end{array}$ & $\begin{array}{l}\text { Ad hoc observation } \\
\text { of activities at } \\
\text { the field huts } \\
\text { and one-to-one } \\
\text { communication } \\
\text { with team members }\end{array}$ & $\begin{array}{l}\text { Action: team mem- } \\
\text { bers and take-over } \\
\text { visitors } \\
\text { Monitoring: TCO/ } \\
\text { SCO }\end{array}$ & $\begin{array}{l}\text { TCO/SCO to inform } \\
\text { DEAT DAI of breaches and } \\
\text { DEAT to revoke permits if } \\
\text { necessary }\end{array}$ \\
\hline & $\begin{array}{l}\text { Rinse cans and } \\
\text { bottles and place } \\
\text { in the waste bins } \\
\text { at the huts }\end{array}$ & $\begin{array}{l}\text { Safe storage and } \\
\text { handling of waste }\end{array}$ & $\begin{array}{l}\text { Ad boc observation } \\
\text { of activities at } \\
\text { the field huts } \\
\text { and one-to-one } \\
\text { communication } \\
\text { with team menbers }\end{array}$ & $\begin{array}{l}\text { Action: team nem- } \\
\text { bers and take-over } \\
\text { visitors } \\
\text { Monitoring: TCO/ } \\
\text { SCO }\end{array}$ & $\begin{array}{l}\text { TCO/SCO to inform } \\
\text { DEAT DAI of breaches and } \\
\text { DEAT to revoke permits if } \\
\text { necessary }\end{array}$ \\
\hline & $\begin{array}{l}\text { Decommission } \\
\text { and close or, } \\
\text { where possible, } \\
\text { remove contents } \\
\text { of all pit toilets } \\
\text { and replace with } \\
\text { removable bucket } \\
\text { system }\end{array}$ & $\begin{array}{l}\text { Minimisation of } \\
\text { persistent pollution; } \\
\text { safe storage and } \\
\text { handling of waste }\end{array}$ & $\begin{array}{l}\text { Annual reporting of } \\
\text { DEAT DAI, sub- } \\
\text { mitted to PEIMA }\end{array}$ & $\begin{array}{l}\text { Action: COs, DEAT } \\
\text { DAI } \\
\text { Monitoring: PEIMA }\end{array}$ & $\begin{array}{l}\text { Annual reporting of PEIMA } \\
\text { to DEAT DG should point } \\
\text { out lack of action on this } \\
\text { point }\end{array}$ \\
\hline & $\begin{array}{l}\text { Replace all field } \\
\text { hut toilet contain- } \\
\text { ers at least once } \\
\text { per year, whether } \\
\text { full or not }\end{array}$ & $\begin{array}{l}\text { Safe storage and } \\
\text { handling of waste }\end{array}$ & $\begin{array}{l}\text { Ensure that rake- } \\
\text { over schedule } \\
\text { accommodates } \\
\text { resupply and waste } \\
\text { removal at all field } \\
\text { huts }\end{array}$ & $\begin{array}{l}\text { Action: COs } \\
\text { Monitoring: Team } \\
\text { leader }\end{array}$ & None \\
\hline
\end{tabular}

1 This example is taken from Goal 7-1-1: Appropriate and sustainable management of waste at the Prince Edward Islands. CO = Conservation Officer; DEAT = Department of Environmental Affairs and Tourism; DAI = Directorate Antarctica and Islands; DG = Director General; SCO $=$ Senior Conservation Officer; TCO = Team Conservation Officer; PEIMA = Prince Edward Islands Management Aurhority. 
Albatrosses and Petrels, and Convention on Wetlands of International Importance especially as Waterfowl Habitat [Ramsar Convention]); to create awareness of the value and fragility of island ecosystems; to support research that contributes to understanding human-induced changes; and to monitor the conservation and management of biota on the islands. These challenges will be met through the implementation of an integrated management system which addresses administration, conservation management, historical conservation and waste management as priority areas for action (table 2). The sections below outline the broad approach to addressing each management goal.

\section{ADMINISTRATION}

\section{Logistics and environmental management}

The plan makes recommendations regarding the institutional arrangements necessary to achieve effective and efficient management of the islands. The EMP places logistic and operational functions within the Department of Environmental Affairs and Tourism's Directorate of Antarctica and Islands, and environmental coordination and monitoring functions within the sister Directorate of Environmental Impact Management.

\section{The Management Authority}

Day-to-day management functions are the responsibility of the Prince Edward Islands Management Authority, which carries out its mandate using the structures and provisions of the EMP. The management authority is a semi-independent body, established by statutory provision, but outside direct control of the implementing structures of government, which reports to the Directorate of Environmental Impact Management. Its tasks include conservation and management of the islands, zoning, issuing permits and Protected Area Notices, evaluation of research proposals and products, implementing an environmental impact assessment procedure for the islands, establishing internal systems and soliciting advice from external parties (advisory committees), recording and reporting to the Minister of Environmental Affairs and Tourism on its deliberations and decisions, and conducting a comprehensive review and evaluation of the EMP every four years. The management authority is the final decisionmaking authority in most of these functions (e.g., permit administration and zoning, internal management, EMP review), but plays an advisory role in a few areas (e.g., adjudication of research proposals).

\section{Personnel}

The isolation of the Prince Edward Islands gives rise to special challenges in the staffing and day-to-day administration of the protected area. A permanent, full-time Senior Conservation Officer (SCO) position for the islands is now in place within the Directorate of Environmental Impact Management. The SCO is based on the mainland and is responsible for ensuring that the EMP is fully implemented. The SCO serves as an ex officio member and secretary of the Prince Edward Islands Management Authority, and the SCO or at least one suitably trained and deputised ad hoc Conservation Officer accompanies all voyages to the PEI. All other Conservation Officers report to the SCO.

A full-time Team Conservation Officer is appointed to the over-wintering team on Marion Island and is responsible for all conservation issues at the Prince Edward Islands during the over-wintering period, reporting directly to the SCO. The Team Conservation Officer will work closely with the

TABLE 2

\title{
Goals of the Prince Edward Islands Environmental Management Plan'
}

\author{
Administration \\ Limit and manage access to the Prince Edward Islands \\ Control and manage access to management zones within the Prince Edward Islands \\ Prevent any human impact on Prince Edward Island \\ Conservation management \\ Prevent the introduction of alien species and invasive species to the Prince Edward Islands \\ Control and/or eradicate alien and invasive species on the Prince Edward Islands \\ Prevent and control outbreaks of disease amongst birds and seals on and around the Prince Edward Islands \\ Islands \\ helicopters) \\ Historical conservation \\ Protect and conserve the Prince Edward Islands archaeological and palaeontological estate \\ Waste management \\ Implement appropriate and sustainable management of waste at the Prince Edward Islands
}

Protect and manage the biodiversity on and around the Prince Edward Islands through targeted multidisciplinary research

Prevent illegal and unsustainable collection, transport and importation of organisms and biological material from the Prince Edward

Minimise disturbance of flora and fauna on and around the Prince Edward Islands during operation of craft (includes boats and

\footnotetext{
1 In the EMP each goal is followed by the set of objectives, actions, targets and monitoring and remedial actions that is necessary to fully address it.
} 
SCO and Team Leader to handle emergency situations, waste spills or disease outbreaks and contraventions of the EMP. The Construction Conservation Officer is responsible for ensuring that all construction activities on Marion Island are carried out in accordance with the EMP and any additional construction management plans. DEAT may appoint ad hoc Conservation Officers at any time to assist the SCO and the Team Conservation Officer in performing their duties during the annual relief voyage or any other construction, maintenance, emergency or replenishment visits.

\section{Routine management}

The primary goals of the management plan relating to administration of the islands are to control access to the islands and their five management zones, and to implement systems to prevent further human impacts on Prince Edward Island. Visits to the islands are controlled through a permit system, specifying which management zones visitors may enter and the activities they may undertake there. Secondary aims are to set out the reporting responsibilities of the management authority and its obligations for data collection and storage, and to establish a comprehensive capacity- building programme for the national Antarctic programme.

\section{CONSERVATION MANAGEMENT}

The conservation management goals of the Prince Edward Islands EMP centre on the prevention and management of biological invasions and disease outbreaks, minimisation of chemical and physical disturbance, protection of vertebrate populations of conservation significance on and around the islands, and prevention of illegal and unsustainable collection of organisms and biological material. A programme of targeted multidisciplinary research to address emerging conservation problems is proposed.

\section{Prevention of and response to propagule transfer}

Prevention of propagule transfer is centred on routes and vectors of transfer. The supply voyage of the vessel SA Agulhas is regarded as the principal route of transfer, while cargo, personnel and craft are major vectors. Propagule transfer is controlled through thorough cleaning, fumigation and regular inspection of the supply vessel and all its cargo prior to loading. Recommended practices for cargo packing in several locations are described, including the government stores, tertiary institutions and domestic settings. In addition, the EMP applies a measure of supply chain control to ensure that food and other products purchased for the islands are not contaminated at source or en route to the vessel.

The protection of Prince Edward Island is of paramount importance when alien introductions are considered. Marion Island has 13 alien vascular plant species, 25 alien invertebrate taxa (including an isopod, slug, and parasitic wasp species, at least one earthworm species, and several alien springtail and mite species; Chown et al. 2002; Lee et al. 2007) and one alien vertebrate species, the house mouse (Mus musculus Linnaeus, 1758; Jansen van Vuuren \& Chown 2007), while domestic cats (Felis catus Linnaeus,
1758) have been eradicated (Bester et al. 2002). However, only three alien vascular plant species and, so far as is known, five alien invertebrate taxa occur on Prince Edward Island (Chown et al. 1998, Ryan et al. 2003, Hugo et al. 2006). Nonetheless, propagule transfer to Prince Edward Island is an ever-present risk given the regular, though infrequent, transfer of personnel and cargo to Prince Edward Island and the abundance of natural vectors between the islands. In response to this propagule pressure, the new EMP restricts the frequency of visits to Prince Edward Island to one expedition every second year by up to 10 people for a maximum of eight days, and requires that strict measures be applied to control access, quarantine, waste management and transport operations during these visits.

Aircraft are routinely deployed throughout Marion Island, and during every expedition to Prince Edward Island, providing a potential transport mechanism for propagules from either the mainland or the research base to other parts of the island group. To prevent such transfer to Prince Edward Island, the EMP requires that all air and water craft be thoroughly cleaned on board the supply vessel before being deployed on Prince Edward Island. These vehicles may not be operated directly between the two islands but must stop at the supply vessel as a quarantine measure. Outer gear used by personnel must be thoroughly cleaned on the mainland before issue, inspected on board the supply vessel during the "boot washing ceremony" and may not be used on both islands during a single expedition. Certain foodstuffs are prohibited from being taken onto Prince Edward Island.

\section{Control of established alien species}

The EMP recommends that the management authority lists and prioritises all alien species present on the islands, prepares an alien species management strategy and provides guidelines to differentiate between natural and human-mediated introductions to the islands. Control or eradication of the house mouse and several alien vascular plants on Marion Island will be necessary in the near future.

\section{Historical conservation}

The historical conservation policy of the PEI aims to record and preserve sites and objects which have cultural and/or historical significance. Although this policy applies to both islands in the group, neither island's historical sites and artefacts have been surveyed fully.

Management of the islands' archaeological and palaeontological estate is the responsibility of national and provincial heritage agencies. In general, artefacts remain in situ unless seriously threatened by continued exposure, in which case they are either stored in a small museum at the Marion Island research base or returned to the mainland. Collection of archaeological or palaeontological items is prohibited by law unless under permit from the relevant agencies, and private collections must be declared and their contents listed with the National Heritage Resources Agency (National Heritage Resources Act, No. 25 of 1999; Office of the President 1999). 


\section{WASTE MANAGEMENT}

South African legislation and policy promote a "cradle to grave" approach to the management and treatment of waste, through all phases of the waste generation, handling and disposal life-cycle (Department of Environmental Affairs and Tourism 2000). In accordance with government policy, the Prince Edward Islands EMP aims to prevent and minimise waste generation and pollution at source, manage the impacts of unavoidable waste from generation to final disposal, and ensure that waste remains the responsibility of the agencies involved in its generation. Minimisation of waste generation and impact at the islands involves reducing the quantity of primary packaging on goods destined for the islands (where this is not in conflict with bio-sanitary practices), providing recycling and waste minimisation facilities on the islands and supply vessel, and using biodegradable and innocuous products whenever possible.

Waste handling practices on the islands are well developed already, but require refinement to ensure that waste is appropriately and safely separated, handled and stored. In general, the management plan recommends that waste be entered into the highest-level waste stream available using a hierarchical decision framework. For example, the waste generated on highly protected Prince Edward Island is entered into the waste stream of the transport and supply vessel; food, human and burnable waste is processed on the vessel and non-biodegradable, recyclable and hazardous waste is transferred into the mainland waste stream. Similarly, all waste (with the exception of grey water and sewage) generated away from base on Marion Island is stored and returned to base for entry into appropriate waste streams (table 3). As a result, very little waste disposal occurs away from base on Marion Island or on Prince Edward Island and waste is never transferred between islands due to the risk of disease or propagule transmission.

\section{CONCLUSION}

The draft Prince Edward Island EMP proposes a qualitative change in the way the islands are managed and conserved, and provides a level of detail that explicitly guides the management responsibilities of personnel based both on the islands and on the mainland. In other words, objectives are set, the actions required to address these objectives are laid out, the parties responsible for implementing these actions are identified, and remedial actions are explicitly set out in case of any failures in the primary chain from objective to implementing action.

The recently-promulgated National Environmental Management: Protected Areas Act specifies that management plans be drafted or updated for all national protected areas in South Africa. By law, such a management plan must be gazetted within three months of its acceptance by the Minister of Environmental Affairs and Tourism, whereupon it will become law. The EMP was delivered to DEAT in February 2006, and is in the process of being accepted.

TABLE 3

\section{Waste management categories, treatment guidelines and destination waste streams for waste originating on Marion Island}

\begin{tabular}{lll}
\hline Waste type & \multicolumn{1}{c}{ Treatment } & Destination \\
\hline $\begin{array}{l}\text { Reusable and recyclable waste (metal containers and foil, } \\
\text { glass, paper and cardboard, wood, plastic and polysty- } \\
\text { rene, composites, such as foil-lined milk and fruit juice } \\
\text { cartons, non-medical waste-related ash from incinerator) }\end{array}$ & $\begin{array}{l}\text { Washing/cleaning, separa- } \\
\text { tion into clearly marked } \\
\text { containers }\end{array}$ & Mainland \\
$\begin{array}{l}\text { Burnable waste (paper, cardboard, small pieces of wood } \\
\text { and burnable medical waste, candle wax) }\end{array}$ & $\begin{array}{l}\text { Separation of medical and } \\
\text { non-medical waste }\end{array}$ & $\begin{array}{l}\text { Incineration on Marion } \\
\text { Island; ash entered into } \\
\text { mainland waste stream }\end{array}$ \\
$\begin{array}{l}\text { Environmentally hazardous biodegradable waste (waste } \\
\text { water, human waste, food waste) }\end{array}$ & $\begin{array}{l}\text { None at present (nacera- } \\
\text { tion and partial treatment } \\
\text { in new base) }\end{array}$ & Outfall into ocean \\
$\begin{array}{l}\text { Environmentally hazardous non-biodegradable waste } \\
\text { (used oil including cooking oil, mechanical waste, } \\
\text { batreries, laboratory, photographic and radiographic } \\
\text { chemicals, light bulbs) }\end{array}$ & $\begin{array}{l}\text { Principally, cleaning and } \\
\text { separation into identified } \\
\text { storage containers }\end{array}$ & Mainland \\
$\begin{array}{l}\text { Bio-hazardous waste - food (uncooked fish, meat and } \\
\text { all poultry waste, including eggs, chicken, melt water, } \\
\text { bones, dried fruit stones and pips) }\end{array}$ & Freeze \\
$\begin{array}{l}\text { Bio-hazardous waste - non-food (medical sharps, bio- } \\
\text { hazardous medical waste and ash from medical waste } \\
\text { incineration) }\end{array}$ & $\begin{array}{l}\text { Separation into identified } \\
\text { storage containers }\end{array}$ & Mainland \\
\hline
\end{tabular}




\section{REFERENCES}

Bester, M.N., Bloomer, J.P., Van Aarde, R.J., Erasmus, B.H., Van Rensburg, P.J.J., Skinner, J.D., Howell, P.G. \& Naude, T.W. 2002: A review of the successful eradication of feral cats from sub-Antarctic Marion Island, Southern Indian Ocean. South African Journal of Wildlife Research 32: 65-73.

Bergstrom, D.M. \& Chown, S.L. 1999: Life at the front: history, ecology and change on southern ocean islands. Trends in Ecology and Evolution 14: 472-477.

Chown, S.L., Gremmen, N.J.M. \& Gaston, K.J. 1998: Ecological biogeography of Southern Ocean islands: species-area relationships, human impacts, and conservation. American Naturalist 152: 562-575.

Chown, S.L., Rodrigues, A.S.L., Gremmen, N.J.M. \& Gaston, K.J. 2001: World heritage status and conservation of Southern Ocean islands. Conservation Biology 15: 550-557.

Chown, S.L., McGeoch, M.A. \& Marshall, D.J. 2002: Diversity and conservation of invertebrates on the sub-Antarctic Prince Edward Islands. African Entomology 10: 67-82.

Chown, S.L. \& Smith, V.R. 1993: Climate change and the shortterm impact of feral house mice at the sub-Antarctic Prince Edward Islands. Oecologia 96: 508-516.

Daszak, P., Cunningham, A.A. \& Hyatt, A.D. 2000: Emerging infectious diseases of wildlife - threats to biodiversity and human health. Science 287: 443-449.

Department of Environmental Affairs and Tourism 1996: Prince Edward Islands Management Plan. Department of Environmental Affairs and Tourism, Directorate Antarctica and Islands. Pretoria, South Africa: 64 pp.

Department of Environmental Affairs and Tourism 2000: White Paper on Integrated Pollution and Waste Management for South Africa. Government Notice No. 227. Government Gazette of the Republic of South Africa, 407(20978). Cape Town. 17 March 2000: 79 pp.

Department of Environmental Affairs and Tourism 2006: Prince Edward Islands Environmental Management Plan. Version 0.1. Prepared for the Department of Environmental Affairs and Tourism, Directorate Antarctica and Islands, by the DST-NRF Centre of Excellence for Invasion Biology, Stellenbosch University, South Africa: 210 pp.

Gremmen, N.J.M., Chown, S.L. \& Marshall, D.J. 1998: Impact of the introduced grass, Agrostis stolonifera on vegetation and soil fauna communities at Marion Island, sub-Antarctic. Biological Conservation 85: 223-231.
Hänel, C. \& Chown, S.L. 1999: Fifty years at Marion and Prince Edward Islands: a bibliography of scientific and popular literature. South African Journal of Science 95: 87-112.

Hugo, E.A., Chown, S.L. \& McGeoch, M.A. 2006: The microarthropods of sub-Antarctic Prince Edward Island: a quantitative assessment. Polar Biology 30: 109-119.

Jansen van Vuuren, B.J. \& Chown, S.L. 2007: Genetic evidence confirms the origin of the house mouse on sub-Antarctic Marion Island. Polar Biology 30: 327-332.

Lee, J.E., Slabber, S., Jansen van Vuuren, B., van Noort, S. \& Chown, S.L. 2007: Colonisation of sub-Antarctic Marion Island by a non-indigenous aphid parasitoid Aphidius matricariae (Hymenoptera, Braconidae). Polar Biology 30: 1195-1201.

Lombard, A.T., Reyers, B., Schonegevel, L.Y., Cooper, J., SmithAdao, L.B., Nel, D.C., Froneman, P.W., Ansorge, I.J., Bester, M.N., Tosh, C.A., Strauss, T., Akkers, T., Gon, O., Leslie, R.W. \& Chown S.L. 2007: Conserving pattern and process in the Southern Ocean: designing a Marine Protected Area for the Prince Edward Islands. Antarctic Science 19: 39-54.

Nel, D.C. \& Nel, J.L. 1999: Marine debris and fishing gear associated with seabirds at sub-Antarctic Marion Island, $1996 / 97$ and $1997 / 98$, in relation to longline fishing activity. CCAMLR Science 6: 85-96.

Office of the President 1998: National Environmental Management Act, No. 107 of 1998. Government Gazette of the Republic of South Africa 401 (19519). Cape Town. 27 November 1998: $72 \mathrm{pp}$

Office of the President 1999: National Heritage Resources Act, No. 25 of 1999. Government Gazette of the Republic of South Africa 406 (19974). Cape Town. 28 April 1999: $88 \mathrm{pp}$.

Ryan, P.G., Smith, V.R. \& Gremmen, N.J.M. 2003: The distribution and spread of alien vascular plants on Prince Edward Island. African Journal of Marine Science 25: 555-562.

The Presidency 2004a: National Environmental Management: Protected Areas Act, No. 57 of 2003. Government Gazette of the Republic of South Africa 464 (26025). Cape Town. 18 February 2004: 50 pp.

The Presidency 2004b: National Environmental Management: Biodiversity Act, No. 10 of 2004. Government Gazette of the Republic of South Africa 467 (26436). Cape Town. 7 June 2004: 84 pp.

(accepted 24 September 2007) 